\title{
Antioxidant activities and oxidative stress inhibitory effects of ethanol extracts from Cornus officinalis on raw 264.7 cells
}

\author{
Kyung-A Hwang ${ }^{*}$, Yu-Jin Hwang and Jin Song
}

\begin{abstract}
Background: Cornus officinalis, is a deciduous tree native to the eastern Asia, distributes mainly in (e.g. Korea, as well as China, and Japan). It is used as folk medicine to backache, polyuria, hypertension and nervous breakdown. Pharmacological studies have demonstrated that C. officinalis possess anti-oxidant, anti-hyperglycemic, and immune regulatory effects. However, reports on the antioxidant activity of $C$. officinalis have been limited to in vitro radical scavenging studies. Its mechanism of action within the cell at the genetic level especially has not yet been clearly defined. Therefore, we investigated the anti-antioxidant activities of C. officinalis in RAW 264.7 cells.

Methods: The antioxidant activities and protective effects of $C$. officinalis ethanol extract on cell damage and the antioxidant enzyme system in lipopolysaccharide (LPS)-induced oxidative stress-damaged RAW 264.7 cells were assessed. To measure the effects of $C$. officinalis on antioxidant activities, we used the following methods: Total phenol and flavonoid contents, DPPH scavenging activity assay, ABTS scavenging activity assay, FRAP value measurement, xanthine oxidase activity assay, ROS generation measurement and real time PCR.

Results: The total phenol and flavonoid contents of C. officinalis extracts were $27.04 \mathrm{mg}$ GAE/g and $3.70 \mathrm{mg}$ QE/g, respectively. The antioxidant activities of $C$. officinalis extracts increased in a dose-dependent manner: the $I_{50}$ values for DPPH and ABTS radical scavenging activities of C. officinalis extracts were $99.32 \mu \mathrm{g} / \mathrm{mL}$ and $138.51 \mu \mathrm{g} / \mathrm{mL}$, respectively. C. officinalis extracts inhibited xanthine oxidase activity and reactive oxygen species generation. The expression of antioxidant enzymes, Cu/ZnSOD, MnSOD, catalase, and glutathione peroxidase increased upon treatment with $C$. officinalis extracts at $100 \mu \mathrm{g} / \mathrm{mL}$, compared to that in the LPS-treated group.
\end{abstract}

Conclusions: These results suggest the therapeutic potential of C. officinalis extract as an anti-oxidant agent.

Keywords: Cornus officinalis, Oxidative stress, Antioxidant activity

\section{Background}

Reactive oxygen species (ROS) are produced in oxidation processes essential to most living organisms and are essential to produce the energy required to fuel other biological processes. However, excessive production of ROS is damaging to cells because ROS destroy molecules such as DNA and proteins. Thus, ROS play an important role in the pathogenesis of various serious diseases, such as neurodegenerative disorders, cancer, cardiovascular diseases, atherosclerosis, cataracts, and inflammation [1-5].

\footnotetext{
* Correspondence: kah366@korea.kr

Department of Agrofood Resources, National Academy of Agricultural

Science, Rural Development Administration, Wanju-gun, Jeollabuk-do 55365, Republic of Korea
}

The mechanism of inflammation injury partially involves the release of ROS from activated neutrophils and macrophages. ROS propagate inflammation by stimulating the release of cytokines such as interleukin-1, tumor necrosis factor- $\alpha$, and interferon- $\alpha$, which stimulate recruitment of additional neutrophils and macrophages. Free radicals are important mediators that provoke or sustain inflammatory processes, and consequently, eir neutralization by antioxidants and radical scavngers can attenuate inflammation [6, 7]. Therefore, these radicals could have therapeutic potential.

There are two methods of suppressing ROS. First, natural defense mechanisms present in the human/mammalian 
system counteract the potential deleterious effects of ROS. Normally, cells have antioxidant systems that protect against the harmful effects of ROS, including superoxide dismutase (SOD), which converts superoxide anions to hydrogen peroxide $\left(\mathrm{H}_{2} \mathrm{O}_{2}\right)$ for rapid removal by detoxifying enzymes such as glutathione peroxidase (GPx). Similarly, glutathione $(\mathrm{GSH})$ can reduce ROS for GPx-catalyzed $\mathrm{H}_{2} \mathrm{O}_{2}$ reductions [8, 9]. Second, functional components from the external environment such as flavonoids, Lascorbic acid (Vit C), and $\alpha$-tocopherol (Vit E), act as antioxidants $[10,11]$. Therefore, a diet rich in antioxidants could help the body defend itself against the molecular effects of free radicals and ROS and hinder the development of many chronic diseases. Numerous studies have shown that natural dietary compounds can potently modulate oxidative stress. Plant phenolics, flavonoids, tannins, and anthocyanins have useful properties such as antioxidant, immune, and anticancer activities. The presence of these antioxidants increases the efficacy of the protection system against ROS [12-14].

Cornus officinalis (Cornaceae) is a deciduous tree native to eastern Asia (e.g., Korea, China, and Japan). The fruit of C. officinalis, known as "Sansuyu" in Korean, is mainly harvested in the central and southern regions of Korea [15]. C. officinalis is often included in traditional treatments for conditions such as backache, polyuria, hypertension, and nervous breakdown [16]. Pharmacological studies have demonstrated that $C$. officinalis possesses antioxidant [17], antihyperglycemic [18], immune regulatory [19] and anti-inflammatory effects [20].

Furthermore, many functional compounds such as ursolic acid, tartaric acid, malic acid, glucosides, and fatty acids are present in the fruit. Several studies have also reported that these compounds have antioxidant and anti-inflammatory effects [21-24].

Reports on the antioxidant activity of $C$. officinalis have been restricted to in vitro radical scavenging studies. Its mechanism of action within the cell at the genetic level has not yet been clearly defined. Therefore, the aims of this study were to identify the effect of C. officinalis on antioxidant activity, inhibition of ROS production, and antioxidant-related gene expression in RAW 264.7 cells (murine macrophage cell line). This study suggests that the ethanol extract of $C$. officinalis could be used as a natural source of antioxidants in the food and pharmaceutical industries.

\section{Methods}

\section{Reagents}

Folin-Denis reagent, sodium carbonate, aluminum chloride, potassium acetate, potassium persulfate, 1,1diphenyl-1-picrylhydrazyl (DPPH), 2,2'-azinibis 3-ethyl benzothiazoline-6-sulfonic acid (ABTS), 2,4,6-tris(2-pyridyl)-s-triazine (TPTZ), iron(III) chloride hexahydrate, gallic acid, acetic acid, lipopolysaccharide (LPS), 3-(4,5-dimethylthiazol-2-yl)-2,5-diphenyltetrazolium bromide (MTT), ascorbic acid (Vit C), and quercetin were purchased from Sigma-Aldrich (St. Louis, MO, USA). Iron (II) sulfate heptahydrate $\left(\mathrm{FeSO}_{4}\right)$ was purchased from Junsei (Tokyo, Japan). Dulbecco's Modified Eagle's Medium (DMEM), fetal bovine serum (FBS), phosphate-buffered saline (PBS), penicillin-streptomycin (P/S), and trypsin-EDTA were obtained from Gibco (Waltham, MA, USA). The xanthine oxidase $(\mathrm{XO})$ assay kit was purchased from Abcam (Cambridge, MA, USA). The other reagents used were of analytical grade.

\section{Sample preparation and extraction}

C. officianalis was purchased from Korea Medicine Herbal Association, which is under the jurisdiction of the Ministry of Agriculture, Food and Rural Affairs (Seoul, Korea). The plant was identified and authenticated by the Korea Medicine Herbal Association. Voucher specimens (NAAS-15-03) were deposited at the Department of Agrofood Resources Herbarium, National Academy of Agricultural Science, Korea. C. officianalis (20 g) was extracted twice with $70 \%$ ethanol at $70{ }^{\circ} \mathrm{C}$ for $6 \mathrm{~h}$. The $70 \%$ ethanol extract was filtered using filter paper (Advantec, Tokyo, Japan). Subsequently, the filtrates were combined and evaporated under vacuum (EYELA CCA-1110, Tokyo Rikakikai Co., Tokyo, Japan) and then lyophilized with a freeze dryer (Ilshine Lab, Suwon, Korea) at $-70{ }^{\circ} \mathrm{C}$ under reduced pressure $(<20 \mathrm{~Pa})$. The dry residue was stored at $-70{ }^{\circ} \mathrm{C}$. For further analysis, the dry extract was reconstituted with dimethyl sulfoxide (DMSO).

\section{Total phenolic content}

The total phenol content of C. officianalis extract was determined by the Folin-Ciocalteau method [25]. The extract was oxidized with Folin-Ciocalteau reagents, and then the reaction was neutralized with saturated sodium carbonate. After incubation at room temperature for $1 \mathrm{~h}$, the absorbance of the reaction mixture was measured at $725 \mathrm{~nm}$ using a microplate reader (Molecular Devices, Sunnyvale, CA, USA). The total phenolic content is expressed as gallic acid equivalents in milligrams per gram (mg GAE/g) of dry extract.

\section{Total flavonoid content}

A sample solution was mixed with $100 \%$ ethanol, $10 \%$ aluminum chloride, $1 \mathrm{M}$ potassium acetate, and distilled water. The reagents were thoroughly mixed and allowed to stand for $40 \mathrm{~min}$ at room temperature, and the absorbance of the supernatant was measured at $415 \mathrm{~nm}$ [26]. Quercetin was used to plot a standard calibration curve, and the results are expressed as quercetin equivalents in milligram per gram (mg QE/g) of dried extract. 


\section{DPPH radical-scavenging activity}

The DPPH radical-scavenging activity was carried out according to the Blois method [27]. DPPH $(0.3 \mathrm{mM})$ was added to each sample. After incubation for $30 \mathrm{~min}$ in the dark at room temperature, the absorbance was measured at $518 \mathrm{~nm}$ using a microplate reader. Vit $C$ was used as a positive control. The free radical-scavenging capacity was expressed by $\mathrm{IC}_{50}$.

\section{ABTS radical cation-scavenging activity}

The ABTS assay was performed to evaluate the ability of the $C$. officianalis extract to scavenge the ABTS radical cation in comparison to that of a standard (Vit C) [28]. The radical cation was prepared by mixing $7 \mathrm{mM}$ ABTS with $2.45 \mathrm{mM}$ potassium persulfate $(1: 1 \mathrm{v} / \mathrm{v})$ and leaving the mixture for $24 \mathrm{~h}$ until the reaction was completed and the absorbance was stable. The ABTS radical solution was diluted with PBS to an absorbance of 0.7 $( \pm 0.02)$ at $732 \mathrm{~nm}$. The assay was conducted with diluted ABTS radical solution mixed with samples, and the measurements were taken at $734 \mathrm{~nm}$ after $30 \mathrm{~min}$. The antioxidative activity of the samples was calculated by determining the decrease in absorbance. The free radical-scavenging capacity was expressed by $\mathrm{IC}_{50}$.

\section{Ferric-reducing antioxidant power (FRAP) activity}

FRAP activity was determined using manual assay methods [29]. The working fluid was freshly prepared by mixing acetate buffer $(300 \mathrm{mM}, \mathrm{pH} 3.6)$ with $10 \mathrm{mM}$ TPTZ in $\mathrm{HCl}$ and $20 \mathrm{mM}$ iron (III) chloride hexahydrate. The sample solution or Vit $\mathrm{C}$ was added to working fluid, and the mixture was left for $4 \mathrm{~min}$ at room temperature. The absorbance was measured at $593 \mathrm{~nm}$. The results are expressed as $\mathrm{FeSO}_{4}$ equivalents.

\section{Cells and culture}

RAW 264.7 cell lines were purchased from the Korean Cell Line Bank (Seoul, Korea). The cell lines were grown in DMEM with $10 \% \mathrm{FBS}$ and $1 \% \mathrm{P} / \mathrm{S}$, and incubated at $37{ }^{\circ} \mathrm{C}$ in $5 \% \mathrm{CO}_{2}$.

\section{Cell cytotoxicity assay}

RAW 264.7 cells were plated at $1 \times 10^{4}$ cells/well. The $C$. officianalis ethanol extract in DMSO was diluted in PBS to obtain final concentrations of 10,50 , and $100 \mu \mathrm{g} / \mathrm{mL}$. Cells were treated with samples for $24 \mathrm{~h}$ and MTT solution was added. After $4 \mathrm{~h}$, the media were removed and DMSO was added to each well. The resulting absorbance was measured at $540 \mathrm{~nm}$.

\section{Xanthine oxidase inhibitory activity assay}

$\mathrm{XO}$ inhibitory activity was assayed using a commercial xanthine oxidase assay kit (Abcam, Cambridge, MA, USA) according to the manufacturer's instructions.
Briefly, RAW 264.7 cells were plated at $5 \times 10^{5}$ cells/well. After $4 \mathrm{~h}$, the cells were treated with 10, 50, and $100 \mu \mathrm{g} /$ $\mathrm{mL}$ of $C$. officianalis for $24 \mathrm{~h}$. The treated cell pellets were mixed with assay buffer and the supernatants were isolated. The working solutions were added to the supernatants and incubated at $37{ }^{\circ} \mathrm{C}$. After $1 \mathrm{~h}$, the absorbance was measured at $570 \mathrm{~nm}$.

\section{Intracellular reactive oxygen species scavenging activity} RAW 264.7 cells were plated at $1 \times 10^{6}$ cells/well. After $4 \mathrm{~h}$, the cells were treated with 10,50 , and $100 \mu \mathrm{g} / \mathrm{mL} \mathrm{C}$. officianalis and LPS for $24 \mathrm{~h}$. After incubation, the cells were washed with PBS and harvested. The cells were then incubated with dichlorofluorescein diacetate (DCFDA) $(25 \mu \mathrm{M})$ for $30 \mathrm{~min}$ at $37^{\circ} \mathrm{C}$ in the dark. After several washings with $\mathrm{PBS}$, the fluorescence was captured using a FACSCalibur flow cytometer (BD Biosciences, San Jose, CA, USA). DCF fluorescence was measured at an excitation wavelength of $488 \mathrm{~nm}$ and emission wavelength of 515-540 $\mathrm{nm}$.

Real-time reverse transcription polymerase chain analysis To determine the expression levels of $\mathrm{Cu} / \mathrm{Zn}$ SOD, Mn SOD, catalase, and GPx, real-time reverse transcription polymerase chain reaction (RT-PCR) was performed using a real-time thermal cycler Qiagen Rotorgene Q (Valencia, CA, USA), in accordance with the manufacturer's instructions. The cells were treated with $C$. officianalis extracts and cultured for $24 \mathrm{~h}$. Thereafter, cDNA was synthesized from the total RNA isolated from cells. The PCR reaction was performed using the $2 \mathrm{X}$ SYBR Green mix (Qiagen, Valencia, CA, USA). All results were normalized to glyceraldehyde 3-phosphate dehydrogenase $($ GAPDH) expression. The following primer sequences were used for real-time RT-PCR: GAPDH, $5^{\prime}$-GAG CCA AAA GGG TCA TCA TC-3' (forward), 5'-TAA GCA GTT GGT GGT GCA GG-3' (reverse); Cu/Zn SOD, 5' CAG CAT GGG TTC CAC GTC CA-3' (forward), 5'CAC ATT GGC CAC ACC GTC CT-3' (reverse); Mn SOD, 5' -GGG TTG GCT TGG TTT CAA TAA GGA A3' (forward), 5' -AGG TAG TAA GCG TGC TCC CAC ACA T-3' (reverse); catalase, 5' -AAG ACA ATG TCA CTC AGG TGC GGA-3' (forward), 5'-GGC AAT GTT CTC ACA CAG GCG TTT-3' (reverse); and GPx, 5'CTC GGT TTC CCG TGC AAT CAG-3' (forward), 5'GTG CAG CCA GTA ATC ACC AAG-3' (reverse).

\section{Statistical analysis}

Statistical analysis was performed using SPSS (version 17.0; SPSS Inc., Chicago, IL, USA). Descriptive statistics were used to calculate the mean and standard error of the mean (SEM). One-way analysis of variance was performed, and when significance $(p<0.05)$ was found, the 
differences of mean values were identified with Duncan's multiple range tests.

\section{Results and Discussion \\ Total phenolic and flavonoid contents}

The total phenolic and flavonoid contents of the C. officianalis extract were determined through a linear gallic acid and quercetin standard curve and are expressed as $\mathrm{mg}$ GAE/g and mg QE/g, respectively. As shown Table 1, the total phenolic and flavonoid contents of $C$. officianalis were $27.04 \pm 0.61 \mathrm{mg} \mathrm{GAE} / \mathrm{g}$ and $3.70 \pm 0.08 \mathrm{mg} \mathrm{QE} /$ $\mathrm{g}$, respectively. According to Jeon et al. [30], the total phenolic and flavonoid contents of C. officianalis ethanol extract were $34.22 \mathrm{mg} / \mathrm{g}$ and $5.67 \mathrm{mg} / \mathrm{g}$, respectively, similar to our findings.

Phenolic compounds have been reported to be associated with antioxidant activity, anticancer effects, and other biological functions, and may prevent the development of aging and disease [31-33]. Thus, our study results suggest that $C$. officianalis extracts might have high antioxidant activities.

\section{Antioxidant capacities of $C$. officianalis}

ROS scavenging has been reported to be a very important antioxidant mechanism in inhibiting lipid oxidation and aging in the human body [34].

The radical scavenging capacities, as determined by DPPH, ABTS and FRAP assays, are shown in Fig. 1. Upon interacting with $\mathrm{DPPH}$, antioxidants transfer either an electron or a hydrogen atom to DPPH, thus neutralizing its free radical character. Therefore, absorption at $518 \mathrm{~nm}$ is proportional to the amount of residual DPPH [35]. The radical scavenging activity was found to be $28.4 \%, 40.9 \%$, and $52.44 \%$, at 10,50 , and $100 \mu \mathrm{g} / \mathrm{mL}$ of C. officianalis ethanol extract $\left(\mathrm{IC}_{50}=99.32 \mu \mathrm{g} / \mathrm{mL}\right)$, respectively. Our results $\left(\mathrm{IC}_{50}=99.32 \mu \mathrm{g} / \mathrm{mL}\right)$ were higher than those obtained by Jeon et al. $\left(\mathrm{IC}_{50}=154 \mu \mathrm{g} /\right.$ $\mathrm{mL}$ ) [31]. DPPH radical scavenging activity is hypothesized to depend on the growth and extraction conditions of C. officinalis.

The ABTS assay measures the relative ability of an antioxidant to scavenge the ABTS generated in the aqueous phase by reacting a strong oxidizing agent (potassium persulfate) with ABTS salt. Reduction of the blue-green ABTS radical solution is measured [29]. The

Table 1 Total phenolic and flavonoids contents of Cornus officinalis ethanol extract

\begin{tabular}{|c|c|c|}
\hline Sample & $\begin{array}{l}\text { Total polyphenol } \\
\text { (mg GAE/g) }\end{array}$ & $\begin{array}{l}\text { Total flavonoid } \\
\text { (mg QE/g) }\end{array}$ \\
\hline Cornus officinalis & $27.04 \pm 0.61$ & $3.70 \pm 0.08$ \\
\hline
\end{tabular}

C. officianalis ethanol extract was shown to have scavenging activity in a dose-dependent manner; the scavenging activity was $40.7 \%$ after exposure to $100 \mu \mathrm{g} / \mathrm{mL}$ of C. officianalis.

The FRAP assay measures total antioxidant activity via the reduction of the ferric tripyridyltriazine $\left(\mathrm{Fe}^{3+}\right.$-TPTZ) complex to the ferrous form [30]. The ferric complexreducing ability of $C$. officianalis was similar to the results obtained for the radical scavenging assay. C. officianalis $(100 \mu \mathrm{g} / \mathrm{mL})$ demonstrated the highest FRAP value (241.5 mM), similar to that of Vit C (256.1 mM), the positive control.

According to Hwang et al. [36], antioxidant activity, as observed in DPPH, ABTS, and FRAP assays, highly correlates with the total phenolic content. Therefore, in the present study, the excellent antioxidant activity of $C$. officianalis indicates a high phenolic content.

\section{Cell cytotoxicity assay}

The cytotoxic effects of C. officianalis on RAW 264.7 cells were determined by exposing the cells to various concentrations of $C$. officianalis $(10,50$, and $100 \mu \mathrm{g} / \mathrm{mL})$ for $24 \mathrm{~h}$. Our results showed that there was no cytotoxic effect on RAW 264.7 cells at the tested concentration (Fig. 2). Therefore, ethanol extracts of C. officianalis with concentrations from 10 to $100 \mu \mathrm{g} / \mathrm{mL}$ were selected for subsequent experiments.

\section{XO inhibitory activity}

$\mathrm{XO}$, an enzyme present in significant concentrations in the gastrointestinal tract and liver, is responsible for the metabolism of hypoxanthine and xanthine to uric acid in the purine catabolic pathway, which produces superoxide radicals. XO is an important biological source of superoxides and has been reported to be present in various pathological processes [37]. In recent years, a number of research groups have investigated potential $\mathrm{XO}$ inhibitors from a wide variety of traditional folk medicines.

We confirmed the inhibitory effects of $C$. officianalis ethanol extract on XO activity. As shown in Fig. 3, XO activity decreased in a dose-dependent manner; the inhibitory effects were $100.5 \%, 85.0 \%$, and $57.0 \%$ at 10 , 50 , and $100 \mu \mathrm{g} / \mathrm{mL}$ of $C$. officianalis ethanol extract, respectively.

In a study by Kim et al. [38], plant polyphenols were found to inhibit enzyme activity by binding to the enzyme-substrate complex instead of directly binding to the active site of the enzyme. Therefore, the XO inhibitory activity observed by $C$. officianalis may be due to polyphenols in C. officianalis. Further studies based on the purification and identification of the polyphenol from $C$. officianalis extract is necessary to investigate the exact mechanism of XO inhibitory activity. 

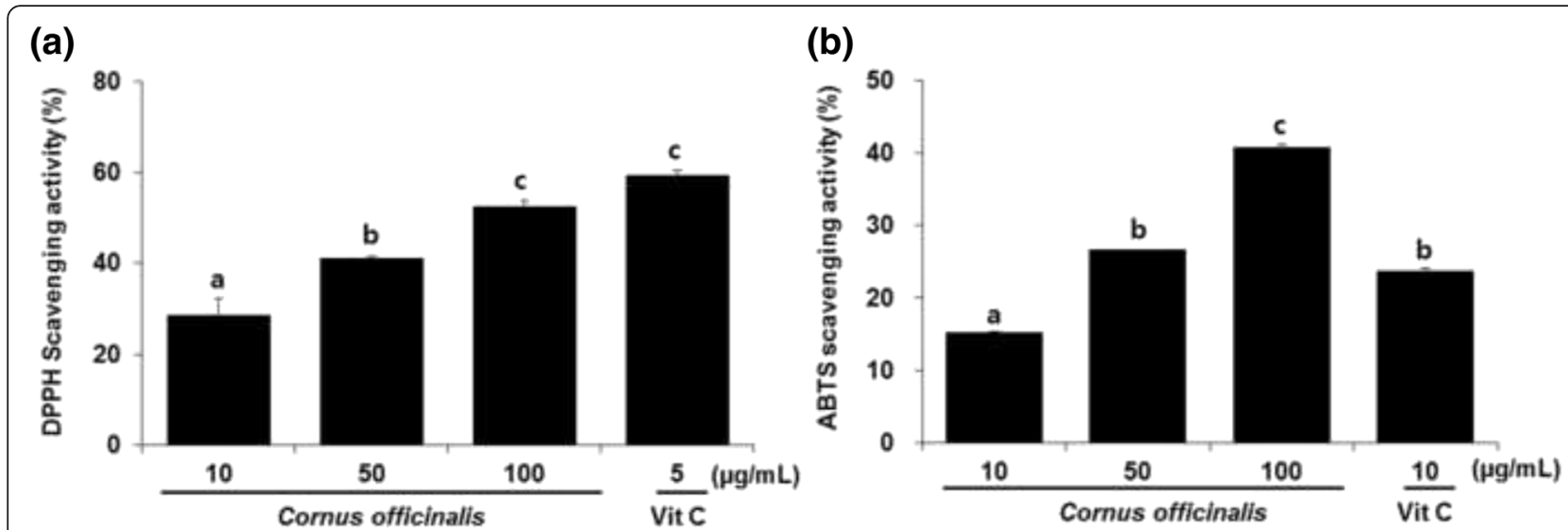

(c)

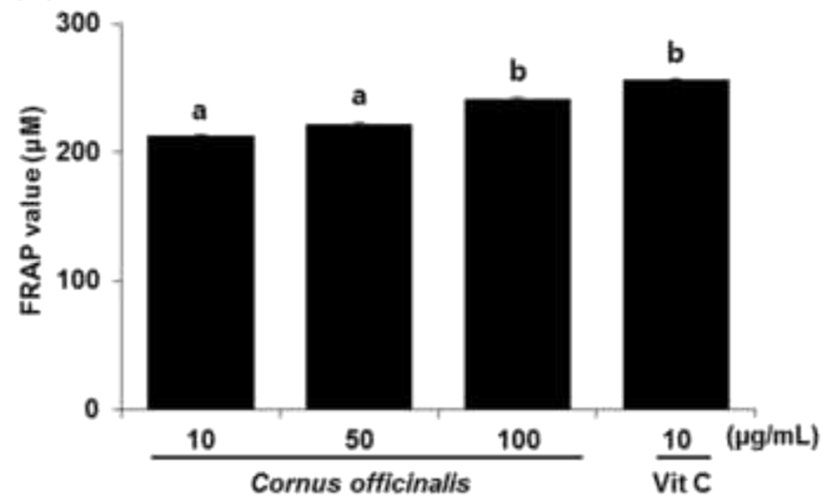

Fig. 1 Antioxidant activities of various concentrations of Cornus officinalis. a DPPH scavenging activity. b ABTS radical scavenging activity. c FRAP value. Values are the mean \pm SEM of experiments in triplicate $(n=3)$. Values expressed by different letters are significantly different at $p<0.05$

Intracellular reactive oxygen species scavenging activity To investigate the intracellular levels of ROS, the cellpermeable probe DCF-DA was utilized. Non-fluorescent DCF-DA, hydrolyzed to DCFH inside the cells, yields highly fluorescent DCF-DA in the presence of intracellular hydrogen peroxide and related peroxides [39]. We examined whether $C$. officianalis extract inhibited LPSinduced ROS generation. As shown in Fig. 4, LPS treatment significantly increased ROS formation in RAW 264.7 cells, as determined by DCF fluorescence. However, treatment with $C$. officianalis extract blocked LPSinduced ROS generation, similar to the results obtained

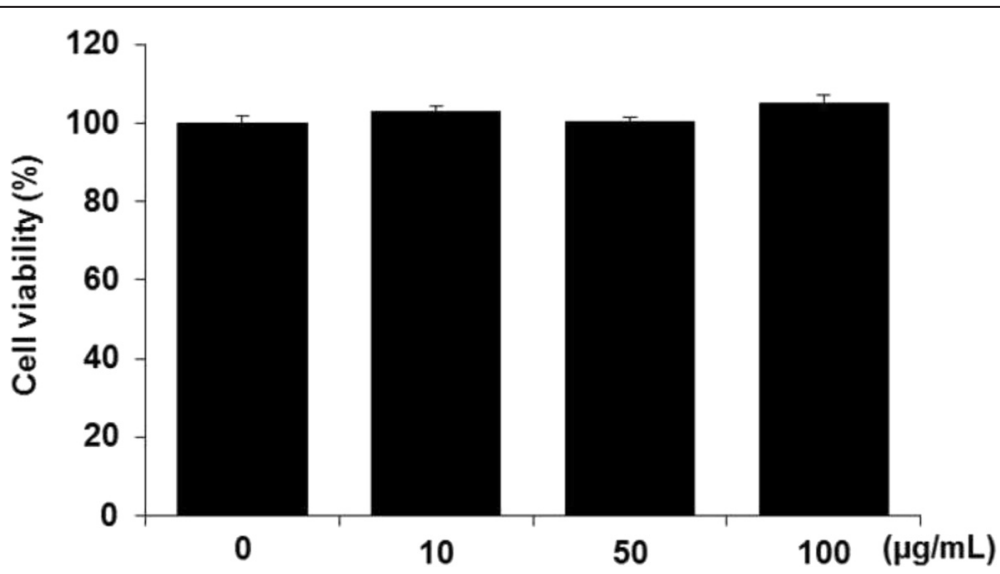

Fig. 2 Cytotoxicity effect of Cornus officinalis on RAW 264.7 cells. Cells were treated with Cornus officinalis at different concentrations (10, 50, and $100 \mu \mathrm{g} / \mathrm{mL}$ ). After treatment for $24 \mathrm{~h}$, cell viability was measured with the MTT assay. Values are the mean \pm SEM of experiments in triplicate $(n=3)$ 


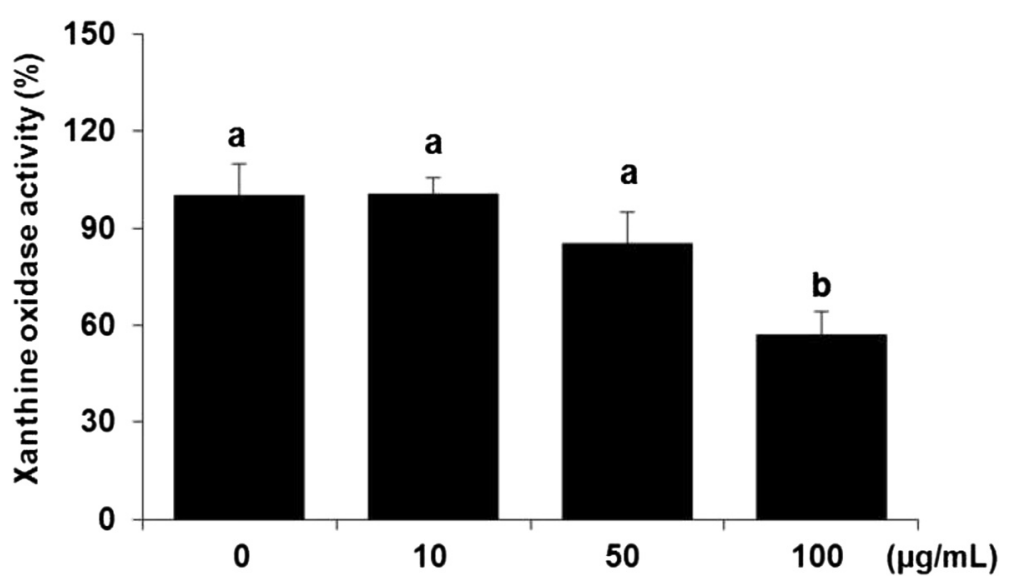

Fig. 3 Xanthine oxidase inhibitory effect of various concentrations of Cornus officinalis on RAW 264.7 cells. Cells were treated with Cornus officinalis at different concentrations $(10,50$, and $100 \mu \mathrm{g} / \mathrm{mL}$ ). After treatment for $24 \mathrm{~h}$, xanthine oxidase activity was measured with a commercial kit. Values are the mean \pm SEM of experiments in triplicate. Values expressed by different letters are significantly different at $p<0.05$

from the antioxidant assays. This evidence suggests that C. officianalis extract may prevent the formation of ROS.

\section{Genes and protein expression of antioxidant enzymes}

We assessed whether C. officianalis ethanol extract affected the expression of genes associated with the antioxidative system, such as $\mathrm{Cu} / \mathrm{Zn}-\mathrm{SOD}, \mathrm{Mn}-\mathrm{SOD}$, catalase, and GPx genes, in RAW 264.7 cells. Our data show that $C$. officianalis ethanol extract significantly increased the expression of $\mathrm{Cu} / \mathrm{Zn}-\mathrm{SOD}, \mathrm{Mn}-\mathrm{SOD}$, catalase, and GPx compared to that in the LPS-induced control group at $100 \mu \mathrm{g} / \mathrm{mL}$ (Fig. 5). To rule out general defects in oxidative stress in RAW 264.7 cells, the cells were treated with $\mathrm{H}_{2} \mathrm{O}_{2}$. The increased oxidative stress is related to an overproduction of free radicals or deficiency in the antioxidant defense system. The mRNA expression of antioxidant-related enzymes was reduced. However, the C. officianalis-treated group showed an increase in the antioxidant-related enzyme mRNA levels
(Additional file 1: Figure S1). In addition, we confirmed that $C$. officianalis ethanol extract was indeed responsible for the antioxidant activity in $\mathrm{H}_{2} \mathrm{O}_{2}$-induced RAW 264.7 cells by analyzing $\mathrm{Cu} / \mathrm{Zn}-\mathrm{SOD}, \mathrm{MnSOD}$, catalase, and GPx expression by immunoblotting. Similar to the gene expression results, the antioxidant enzyme levels increased in the C. officianalis-treated cells (Additional file 1: Figure S2).

The SODs convert superoxide radicals into hydrogen peroxide and molecular oxygen $\left(\mathrm{O}_{2}\right)$, while catalase and GPx convert hydrogen peroxide into water, and in the case of catalase, to oxygen and water. During homeostasis, SOD sufficiently inactivates superoxides. However, during pathological states such as oxidative stress and diseases, increased levels of superoxides are not inactivated by SOD in the cells and can result in ROS-induced damage. There are three SOD enzymes. MnSOD is localized in the mitochondria, $\mathrm{Cu} / \mathrm{ZnSOD}$ is located in the cytoplasm and nucleus, and ECSOD is expressed

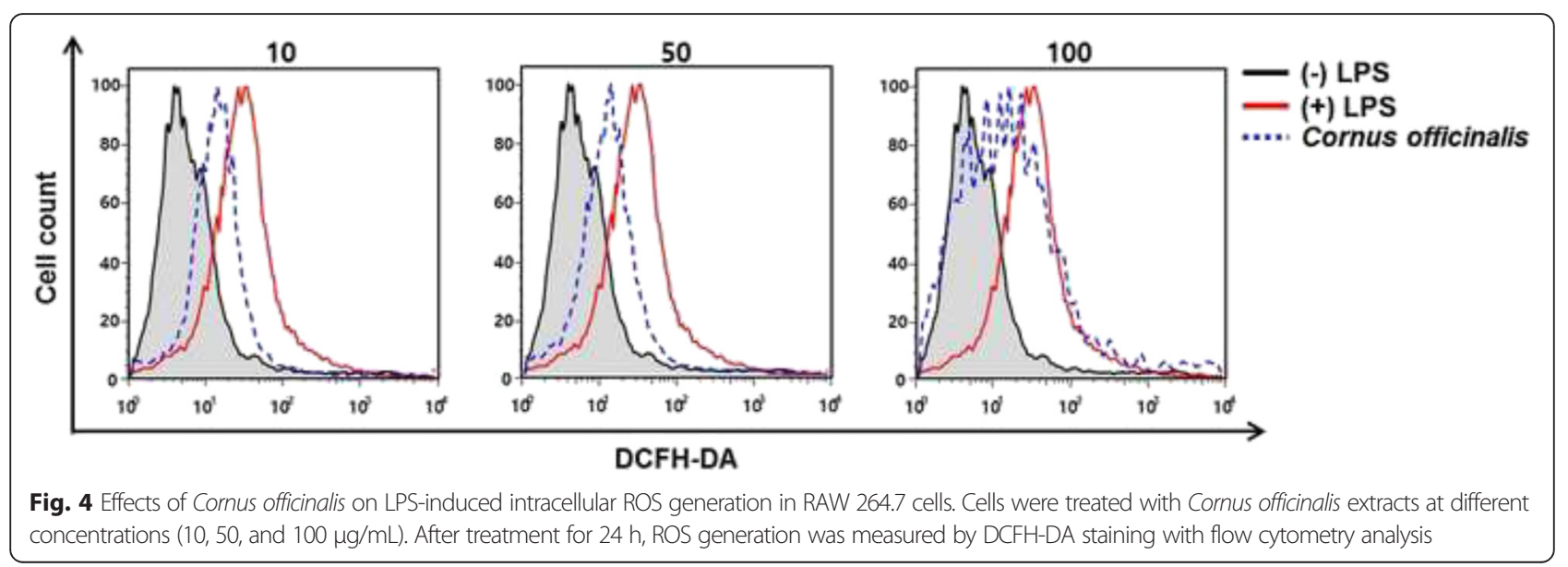




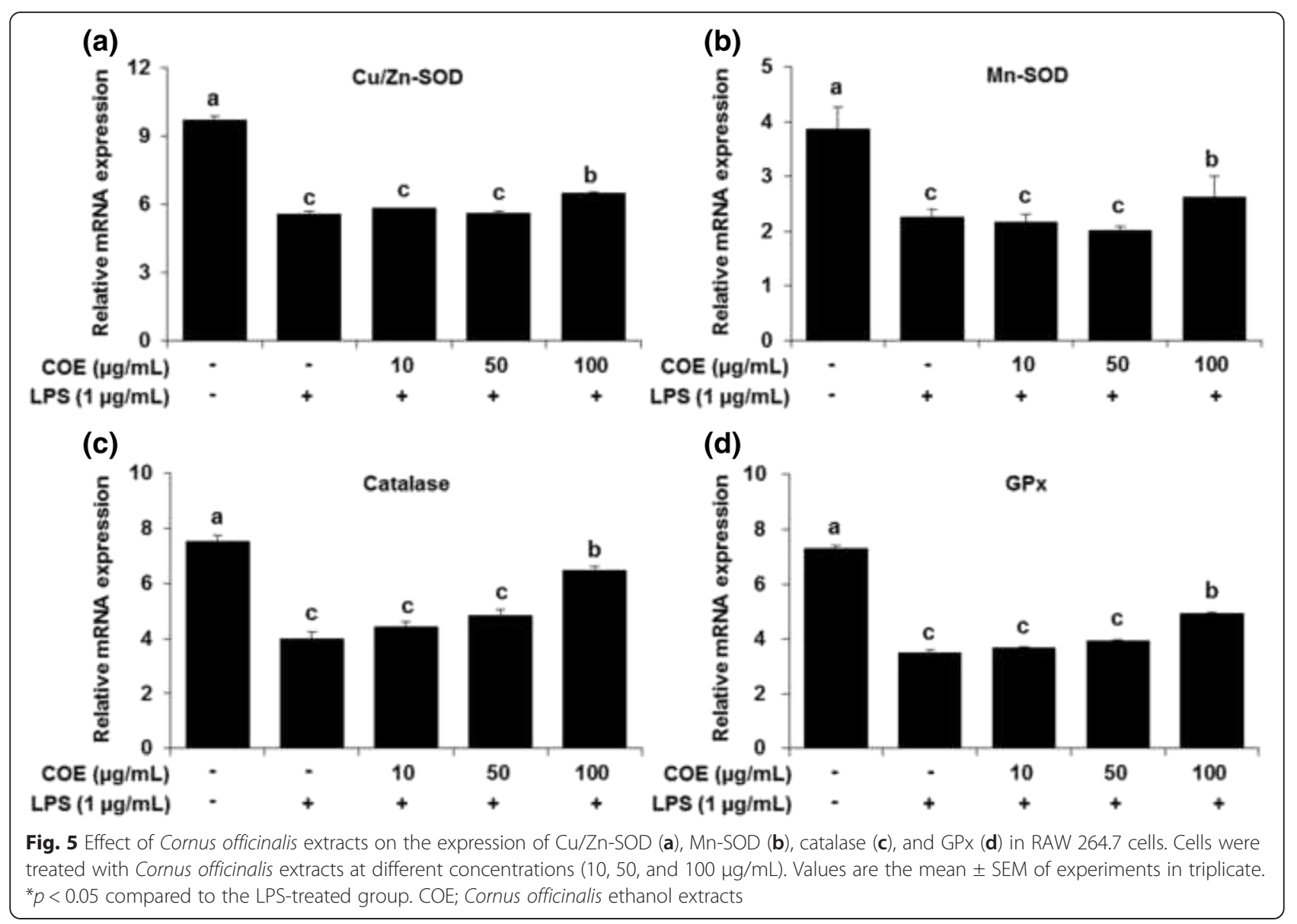

extracellularly in some tissues. Other antioxidant enzymes include catalase, which is found in peroxisomes and cytoplasm, and GPx, which can be found in many subcellular components including the mitochondria and nucleus [40-42]. In our results, the C. officianalis ethanol extract suppressed oxidative stress by increasing antioxidant enzyme activities including those of SOD, catalase, and GPx. Thus, C. officianalis ethanol extract may have a strong antioxidant effect due to $C$. officianalis-induced activation of antioxidative enzymes at different locations within the cells.

These antioxidant enzyme activities are positively correlated with antioxidant effects. The main function of antioxidant enzymes is to neutralize free radicals. Antioxidant enzymes may interrupt an oxidizing chain reaction to minimize the damage caused by free radicals. The risk of acquiring free-radical-related diseases could be reduced by decreasing exposure to free radicals and increasing the intake of antioxidants and antioxidant enzyme-rich foods. Many studies have shown a strong positive linear correlation between antioxidant capacity and antioxidant enzymes of medicinal herbs and other dietary plants. Moreover, these results have also suggested that antioxidant enzyme activity is responsible for their antioxidant capacity [43-45]. In the present study, our data showed that $C$. officianalis extract has potent free radical-scavenging capacities for $\mathrm{DPPH}$ and ABTS radicals. Antioxidant capacities in $C$. officianalis were highly correlated with their antioxidant enzyme activities. High activity of SOD, catalase, and GPx increased the free radical-scavenging capacity of the $C$. officianalis-treated group. This study has shown that $C$. officianalis ethanol extract had significant antioxidant activity and increased antioxidant enzyme activity. Thus, we suggest that consuming $C$. officianalis fruit may be beneficial to human health.

\section{Conclusion}

The present study found that $C$. officianalis extract has strong antioxidant activity in cells via activation of the antioxidative enzyme system. Further studies of the mechanism of action of these compounds are underway. Based on these results, C. officianalis appears to be a good natural antioxidant agent and could be of 
significance in the food industry for treating various human and animal diseases.

\section{Additional file}

Additional file 1: Figure S1. Effect of Cornus officinalis extracts on the expression of Cu/Zn-SOD (a), Mn-SOD (b), Catalase (c), and GPx (d) genes in RAW 264.7 cells. Cells were treated with $\mathrm{H}_{2} \mathrm{O} 2(100 \mu \mathrm{M})$ and Cornus officinalis extracts at different concentrations $(10,50$, and $100 \mu \mathrm{g} / \mathrm{mL})$. Values are the mean \pm SEM of experiments in triplicate. Values expressed by different letters are significantly different at $p<0.05$. COE; Cornus officinalis ethanol extracts. Figure S2. Effect of Cornus officinalis extracts on the protein expression of antioxidant enzymes in RAW 264.7 cells. Cells were treated with Cornus officinalis extracts at different concentrations $(10,50$, and $100 \mu \mathrm{g} / \mathrm{mL})$. (PPTX $148 \mathrm{~kb})$

\section{Abbreviations}

ABTS, 2,2'-azinibis 3-ethyl benzothiazoline-6-sulfonic acid; DCFH-DA dichlorofluorescein diacetate; DMEM, Dulbecco's modified Eagle's medium; $\mathrm{DPPH}, 1,1$-diphenyl-1-picrylhydrazyl; FBS, fetal bovine serum; $\mathrm{FeSO}_{4}$, sulfate heptahydrate; GAE, gallic acid equivalent; GAPDH, glyceraldehyde 3-phosphate dehydrogenase; GPx, glutathione peroxidase; LPS, lipopolysaccharides; MTT, 3(4,5-dimethylthiazol-2-yl)-2,5-diphenyltetrazolium bromide; P/S, penicillinstreptomycin; QE, quercetin equivalent; ROS, reactive oxygen species; RT-PCR, real-time reverse transcription polymerase chain reaction; SEM, standard error of the mean; SOD, superoxide dismutase; TPTZ, 2,4,6-tris(2-pyridyl)-s-triazine; XO, xanthine oxidase

\section{Acknowledgements}

This study was supported by the "Research Program for Agricultural Science \& Technology Development (Project No. PJ010946)," National Academy of Agricultural Science, Rural Development Administration, Korea.

\section{Funding}

This project was financially supported by National Academy of Agricultural Science, Rural Development Administration, Korea.

\section{Availability of data and materials}

The datasets supporting the conclusions of this article are included within the article and its additional files.

\section{Authors' contributions}

$\mathrm{K}$-AH conceived the study and designed the experiments. Y-JH performed most of the experiments. All authors including JS analyzed the data and discussed the results. K-AH supervised the project and wrote the manuscript with the help of $\mathrm{Y}-\mathrm{JH}$ and JS. All authors read and approved the final manuscript.

\section{Competing interests}

The authors declare that they have no competing interests.

\section{Consent for publication}

This information is not relevant.

\section{Ethics approval and consent to participate}

This information is not relevant.

\section{Received: 7 January 2016 Accepted: 14 June 2016}

Published online: 08 July 2016

\section{References}

1. Stadtman ER, Berlett BS. Reactive oxygen-mediated protein oxidation in aging and disease. Drug Metab Rev. 1998;30:225-43.

2. Valko M, Leibfritz D, Moncol J, Cronin MT, Mazur M, Telser J. Free radicals and antioxidants in normal physiological functions and human disease. Int J Biochem Cell Biol. 2007:39:44-84.

3. Spector A. Oxidative Stress and Disease. J Ocul Pharmacol Ther. 2000;16:193-201.

4. Halliwell B. Antioxidants in human health and disease. Annu Rev Nutr. 1996;16:33-50.
5. Ghosh S, Bishayee K, Paul A, Mukherjee A, Sikdar S, Chakraborty D, Boujedain N. Khuda-Bukhsh AR. Homeopathic mother tincture of Phytolacca decandra induces apoptosis in skin melanoma cells by activating caspase-mediated signaling via reactive oxygen species elevation. J Integr Med. 2013;11:116-24.

6. Khansari N, Shakiba Y, Mahmoudi M. Chronic inflammation and oxidative stress as a major cause of age-related diseases and cancer. Recent Pat Inflamm Allergy Drug Discov. 2009;3:73-80.

7. Delaporte RH, Sanchez GM, Cuellar AC. Anti-inflammatory activity and lipid peroxidation inhibition of iridoid lamiide isolated from Bouchea fluminensis (Vell.) Mold. (Verbenaceae). J Ethnopharmacol. 2002;82:127-30.

8. Feillet-Coudray C, Sutra T, Fouret G, Ramos J, Wrutniak-Cabello C, Cabello G, Cristol JP, Coudray C. Oxidative stress in rats fed a high-fat high-sucrose diet and preventive effect of polyphenols: Involvement of mitochondrial and NAD(P) H oxidase systems. Free Radic Biol Med. 2009;46:624-32.

9. Perry B, Zhang J, Saleh T, Wang Y. Liuwei Dihuang, a traditional Chinese herbal formula, suppresses chronic inflammation and oxidative stress in obese rats. J Integr Med. 2014;12:447-54.

10. Cebral E, Carrasco I, Vantman D, Smith R. Preimplantation embryotoxicity after mouse embryo exposition to reactive oxygen species. Biocell. 2007:31:51-9.

11. Kim SM, Cho YS, Sung SL. The antioxidant ability and nitrite scavenging ability of plant extract. Korean Soc Food Sci Technol. 2001;33:626-32.

12. Khalafalla MM, Abdellatef E, Dafalla HM, Nassrallah AA, Aboul-Enein KM, Lightfoot DA. Active principle from Moringa oleifera Lam leaves effective against two leukemias and a hepatocarcinoma. Afr J Biotechnol. 2010;9: 8467-71.

13. Seog HM, Seo MS, Kim HM, Ahn MS, Lee YT. Anttioxidative activity of barley polyphenol extract (BPE) separated from pearling by-products. Korean Soc Food Sci Technol. 2002;34:889-92.

14. Heinonen M. Antioxidant activity of plant extracts containing phenolic compounds. J Agric Food Chem. 1999:47:3954-62.

15. Joo SJ, Park JH, Seo Bl. Effects of Korean Corni fructus on treatment of osteoporosis in ovariectomized rats. The Korea J Herbology. 2007:22:83-95.

16. Seo Kl, Lee SW, Yang KH. Antimicrobial and antioxidative activities of Corni fructus extracts. Korean J Food Preservation. 1999:6:99-103.

17. Lee NH, Seo CS, Lee HY, Jung DY, Lee JK, Lee JA, Song KY, Shin HK, Lee MY, Seo YB, Kim HK, Ha HK. Hepatoprotective and antioxidative activities of Cornus officinalis against acetaminophen-induced hepatotoxicity in Mice. Evid Based Complement Alternat Med. 2012;2012:804924.

18. Yamahara J, Mibu H, Sawada T, Fujimura J, Takino S. Antidiabetic principles of Corni fructus experimental diabetes induced by streptozotocin. Yakugaku Zasshi. 1981;101:86-90.

19. Dai Y, Hang B, Huang Z. Inhibition of Corni fructus on experimental inflammation. China J Chinese materia medica. 1992:17·307-9.

20. Akhavan N, Feresin R, Johnson S, Pourafshar S, Elam M, Hsieh YH, Arjmandi B. Cornus officinalis Modulates the Production of ProInflammatory Molecules in Lipopolysaccharide-Activated RAW264.7 Macrophages. FASEB J. 2015:29:922-30.

21. Kim YD, Kim HK, Kim KJ. Analysis of nutritional components of Cornus officianalis. J Korean Soc Food Sci Nutr. 2003·32·785-9.

22. Yang $L$, Wang $Z$, Huang $L$. Isolation and structural characterization of a polysaccharide FCAP1 from the fruit of Cornus officinalis. Carbohydr Res. 2010;345:1909-13.

23. Wang MY, Zhao FM, Cai BC. Summary of studies on pharmacological effect of Corni fruit and its active components. Chin Archives Traditional Chin Med. 2008:26:1419-21.

24. Jang SE, Jeong JJ, Hyam SR, Han MJ, Kim DH. Ursolic acid isolated from the seed of Cornus officinalis ameliorates colitis in mice by inhibiting the binding of lipopolysaccharide to Toll-like receptor 4 on macrophages. J Agric Food Chem. 2014;62:9711-21

25. Folin O, Denis W. On phosphotungastic-phosphomolybdic compounds as color reagents. J Biol Chem. 1912;12:239-49.

26. Moreno MIN, Isla MI, Sampietro AR, Vattuone MA. Comparison of the free radical scavenging activity of propolis from several region of Argentina. J Ethnopharmacol. 2000;71:109-14.

27. Blois MS. Antioxidant determination by the use of a stable free radical. Nature. 1958:181:1199-200.

28. Roberta R, Nicoletta P, Anna P, Ananth P, Min Y, Catherine RE. Antioxidant activity applying an improved ABTS radical cation decolorization assay. Free Radic Biol Med. 1999;26:1231-7.

29. Benzie FF, Strain JJ. The ferric reducing ability of plasma (FRAP) as a measure of "Antioxidant power": The FRAP assay. Anal Biochem. 1996;230:70-9. 
30. Jeon YH, Kim MH, Kim MR. Antioxidative, antimutagenic, and cytotoxic activities of ethanol extracts from Cornus officianalis. J Korean Soc Food Sci Nutr. 2008;37:1-7.

31. Gulcin I, Beydemir S. Phenolic compounds as antioxidants: carbonic anhydrase isoenzymes inhibitors. Mini Rev Med Chem. 2013;13:408-30.

32. Kim YH, Lee YJ, Park SO, Lee SJ, Lee OH. Antioxidant compounds and antioxidant activities of fermented black rice and its fractions. Korean Food Sci Technol. 2013;45:262-6.

33. Wu X, Beecher GR, Holden JM, Haytowitz DB, Gebhardt SE, Prior RL. Concentrations of anthocyanins in common foods in the United States and estimation of normal consumption. J Agric Food Chem. 2006:54:4069-75.

34. Koh YJ, Cha DS, Choi HD, Park YK, Choi IW. Hot water extraction optimization of dandelion leaves to increase antioxidant activity. Korean J Food Sci Technol. 2008;40:283-9.

35. Teixeira J, Gaspar A, Garrido EM, Garrido J, Borges F. Hydroxycinnamic acid antioxidants: An electrochemical overview. BioMed Res Int. 2013;1:1-11.

36. Hwang YJ, Lee EJ, Kim HR, Hwang KA. In vitro antioxidant and anticancer effects of solvent fractions from Prunella vulgaris var lilacina. BMC Complement Altern Med. 2013;13:310.

37. Harrison R. Structure and function of xanthine oxidoreductase: where are we now? Free Radic Biol Med. 2002;33:774-97.

38. Kim YJ. Evaluation of Antioxidant activity and thermal stability of plant polyphenols. Biomaterials Res. 2009;13:30-6.

39. Sampath V, Radish AC, Eis AL, Broniowska K, Hogg N, Konduri GG. Attenuation of lipopolysaccharide-induced oxidative stress and apoptosis in fetal pulmonary artery endothelial cells by hypoxia. Free Radic Biol Med. 2009;46:663-71.

40. McCord JM, Keele BB, Fridovich I. An enzyme based theory of obligate anaerobiosis: the physiological function of superoxide dismutase. Proc Natl Acad Sci. 1971;68:1024-7.

41. Liu J, Hinkhouse MM, Sun W, Weydert CJ, Ritchie JM, Oberley LW, Cullen JJ. Redox regulation of pancreatic cancer cell growth: role of glutathione peroxidase in the suppression of the malignant phenotype. Hum Gene Ther. 2004;15:239-50.

42. Weydert CJ, Cullen JJ. Measurement of superoxide dismutase, catalase, and glutathione peroxidase in cultured cells and tissue. Nat Protoc. 2010;5:51-66.

43. Wang SY, Ballington JR. Free radical scavenging capacity and antioxidant enzyme activity in deerberry (Vaccinium stamineum L.). LWT. 2007:40:1352-61.

44. Criado MN, Barba FJ, Frígola A, Rodrigo D. Effect of Stevia rebaudiana on oxidative enzyme activity and its correlation with antioxidant capacity and bioactive compounds. Food Bioprocess Technol. 2014;7:1518-25.

45. Sarikurkcu C, Ozer MS, Tepe B, Dilek E, Ceylan O. Phenolic composition, antioxidant and enzyme inhibitory activities of acetone, methanol and water extracts of Clinopodium vulgare L. subsp. vulgare L. Industrial Crops Products. 2015;76:961-6.

\section{Submit your next manuscript to BioMed Central and we will help you at every step:}

- We accept pre-submission inquiries

- Our selector tool helps you to find the most relevant journal

- We provide round the clock customer support

- Convenient online submission

- Thorough peer review

- Inclusion in PubMed and all major indexing services

- Maximum visibility for your research

Submit your manuscript at www.biomedcentral.com/submit

) Biomed Central 